\title{
A roadmap for Antarctic and Southern Ocean science for the next two decades and beyond
}

\author{
M.C. KENNICUTT II, S.L. CHOWN, J.J. CASSANO, D. LIGGETT, L.S. PECK, R. MASSOM, S.R. RINTOUL, \\ J. STOREY, D.G. VAUGHAN, T.J. WILSON, I. ALLISON, J. AYTON, R. BADHE, J. BAESEMAN, P.J. BARRETT, \\ R.E. BELL, N. BERTLER, S. BO, A. BRANDT, D. BROMWICH, S.C. CARY, M.S. CLARK, P. CONVEY, \\ E.S. COSTA, D. COWAN, R. DECONTO, R. DUNBAR, C. ELFRING, C. ESCUTIA, J. FRANCIS, H.A. FRICKER, \\ M. FUKUCHI, N. GILBERT, J. GUTT, C. HAVERMANS, D. HIK, G. HOSIE, C. JONES, Y.D. KIM, Y. LE MAHO, \\ S.H. LEE, M. LEPPE, G. LEITCHENKOV, X. LI, V. LIPENKOV, K. LOCHTE, J. LÓPEZ-MARTÍNEZ, \\ C. LÜDECKE, W. LYONS, S. MARENSSI, H. MILLER, P. MOROZOVA, T. NAISH, S. NAYAK, R. RAVINDRA, \\ J. RETAMALES, C.A. RICCI, M. ROGAN-FINNEMORE, Y. ROPERT-COUDERT, A.A. SAMAH, L. SANSON, \\ T. SCAMBOS, I.R. SCHLOSS, K. SHIRAISHI, M.J. SIEGERT, J.C. SIMÕES, B. STOREY, M.D. SPARROW, \\ D.H. WALL, J.C. WALSH, G. WILSON, J.G. WINTHER, J.C. XAVIER, H. YANG and W.J. SUTHERLAND \\ mckennicutt@gmail.com
}

\begin{abstract}
Antarctic and Southern Ocean science is vital to understanding natural variability, the processes that govern global change and the role of humans in the Earth and climate system. The potential for new knowledge to be gained from future Antarctic science is substantial. Therefore, the international Antarctic community came together to 'scan the horizon' to identify the highest priority scientific questions that researchers should aspire to answer in the next two decades and beyond. Wide consultation was a fundamental principle for the development of a collective, international view of the most important future directions in Antarctic science. From the many possibilities, the horizon scan identified 80 key scientific questions through structured debate, discussion, revision and voting. Questions were clustered into seven topics: i) Antarctic atmosphere and global connections, ii) Southern Ocean and sea ice in a warming world, iii) ice sheet and sea level, iv) the dynamic Earth, v) life on the precipice, vi) near-Earth space and beyond, and vii) human presence in Antarctica. Answering the questions identified by the horizon scan will require innovative experimental designs, novel applications of technology, invention of next-generation field and laboratory approaches, and expanded observing systems and networks. Unbiased, non-contaminating procedures will be required to retrieve the requisite air, biota, sediment, rock, ice and water samples. Sustained year-round access to Antarctica and the Southern Ocean will be essential to increase winter-time measurements. Improved models are needed that represent Antarctica and the Southern Ocean in the Earth System, and provide predictions at spatial and temporal resolutions useful for decision making. A co-ordinated portfolio of cross-disciplinary science, based on new models of international collaboration, will be essential as no scientist, programme or nation can realize these aspirations alone.
\end{abstract}

Received 6 July 2014, accepted 11 August 2014, first published online 18 September 2014

Key words: extraordinary logistics, future directions, horizon scan, research priorities, Scientific Committee on Antarctic Research, technological challenges

\section{Introduction}

Priority setting exercises are often used to support the achievement of societal goals through a structured identification of critical needs for scientific knowledge and information (Sutherland et al. 2011, Cook et al. 2013a). A clear science agenda, tied explicitly to information needs, is generally welcomed by policy makers and by those faced with difficult choices within a context of finite resources.

Author contact information and contribution are provided in Table S1, SupMat
Researchers likewise find the identification of broad themes and key knowledge gaps helpful for identifying future research areas, potential applications of their work and critical areas in need of knowledge synthesis. Science priority setting is particularly important in the Antarctic given the substantial costs and challenges of conducting research in the region. Although various Antarctic organizations routinely undertake priority setting exercises, often formulated as national strategic or organizational plans, these are short term, and frequently focus on the specific needs and capabilities of an individual entity. To date, comprehensive, long-term 
international priority setting for science in the Antarctic and Southern Ocean has been lacking, with one notable exception being the recent International Polar Year 20072008 (on a 30 to 50 year cycle). Therefore, the goal of the 1st Scientific Committee on Antarctic Research (SCAR) Antarctic and Southern Ocean Science Horizon Scan (hereafter 'scan') was to establish a process that could be routinely used to identify the most important, highest priority scientific questions that Antarctic science should aspire to answer. In this first scan, the timeframe was the next two decades and beyond. Here we outline the scan process and report its outcomes.

\section{Methods}

A horizon scan is a priority setting method that systematically searches for opportunities, which are then used to articulate a vision for future research directions (Sutherland \& Woodroof 2009). The scan methods of Sutherland et al. $(2011,2013)$ were customized to the requirements of Antarctic and Southern Ocean science, which is region-based, includes a wide range of scientific disciplines and research topics, and involves fieldwork in challenging and remote locations. The scan process was designed to be inclusive and transparent. The final list of questions was agreed at a face-to-face gathering (hereafter 'Retreat') held in Queenstown, New Zealand from 20-23 April 2014. There were opportunities to contribute scientific questions and to nominate experts to attend the Retreat. A web site was established which served as a resource and a record of the scan (http://www.scar.org/ horizonscanning/). Retreat invitee selection, pre-Retreat rating of questions and voting were administered using Qualtrics (www.qualtrics.com).

\section{Selection of Retreat attendees}

An International Steering Committee (ISC) of 25 members from 14 countries, appointed by SCAR (http://www. scar.org/horizonscan/isc), selected invitees to the Retreat. Candidates for an invitation were identified through an open, online nomination process. The process generated 789 nominations of 510 individuals. Nominees were classified as experts in one of five categories: i) geosciences, ii) life sciences, iii) physical sciences, iv) social sciences and humanities, and v) policy making. Voting was conducted within categories to ensure broad representation. On the ballot, each nominee had a short resume and a link to a homepage if available. Two rounds of voting by the ISC were conducted. In the first round the top $10 \%$ of vote receivers were moved to a short list and those receiving two or fewer votes were no longer considered. The remaining nominees were voted on a second time and the top $10 \%$ vote receivers were added to the short list bringing it to 115 nominees for the 50 available 'at-large invitations'. ISC members were also extended an invitation to the Retreat for a total of 75 attendees.

The total number of Retreat invitees was constrained by the manageability of the group and the budget. From the short list of nominees, the final invitees were selected to ensure balance amongst disciplinary expertise, geographical origins, gender, stage of career, and representation of SCAR partner organizations and other stakeholders. Retreat invitees were from 22 countries and included scientists, national programme directors/managers, policy makers, and early-career scientists (see Table S1). If an invitee was unable to attend, another invitee with similar qualifications was selected from the short list ( $97 \%$ of initial invitations were accepted). Retreat attendees were considered representatives of their respective communities and were asked to consult with others throughout the scan process. Retreat attendees reported substantive input from $c .700$ colleagues prior to the Retreat.

\section{Generation of initial questions}

Two open, online solicitations generated an initial database of scientific questions. Submitted questions were expected to: i) be answerable by an achievable research design, ii) have a factual answer independent of value judgements, iii) address important gaps in knowledge, iv) be of a spatial and temporal scale that could be addressed by a research team, v) be specifically formulated (not a general topical area), and vi) if related to impact and interventions, contain a subject, an intervention and a measurable outcome (Sutherland et al. 2011). The questions were to be clearly-worded, simple and concise, and drafted to capture the essence of a complex idea. Questions best addressed by research in the southern polar regions or where studies in the Antarctic provide insights unobtainable elsewhere were encouraged. Questions could be important to global issues and/or grounded in curiosity-driven research. Question submitters were asked to think beyond what is being studied today and predict the research needed in the next two decades and beyond, which, when answered, would deliver globally significant Antarctic science.

The initial database consisted of 866 questions: 751 from the first question solicitation and 115 from the second. Unedited questions were sorted into topical areas and some interdisciplinary questions were included under more than one topic (Table I). The database of questions was made publically available and served as the starting point for the Retreat. A pre-Retreat online survey asked attendees to select the top ten questions in the sessions they planned to attend on Day 1 of the Retreat (session attendance was by self-selection). As part of the pre-Retreat survey, attendees had an opportunity to propose additional questions to fill gaps in the coverage of the question database. Thirty-one 
Table I. Groupings of questions for the pre-Retreat survey and Retreat sessions for Day 1 (*totals include questions listed in more than one session), merged Day 2 sessions, and the final Day 3 plenary session ( $n=$ number of questions per session, $\mathrm{G}=$ number of gold questions, $\mathrm{S}=$ number of silver questions, $\mathrm{B}=$ number of bronze questions). The final questions from Day 3 were categorized into topical clusters (with the number and percentage) of questions per cluster.

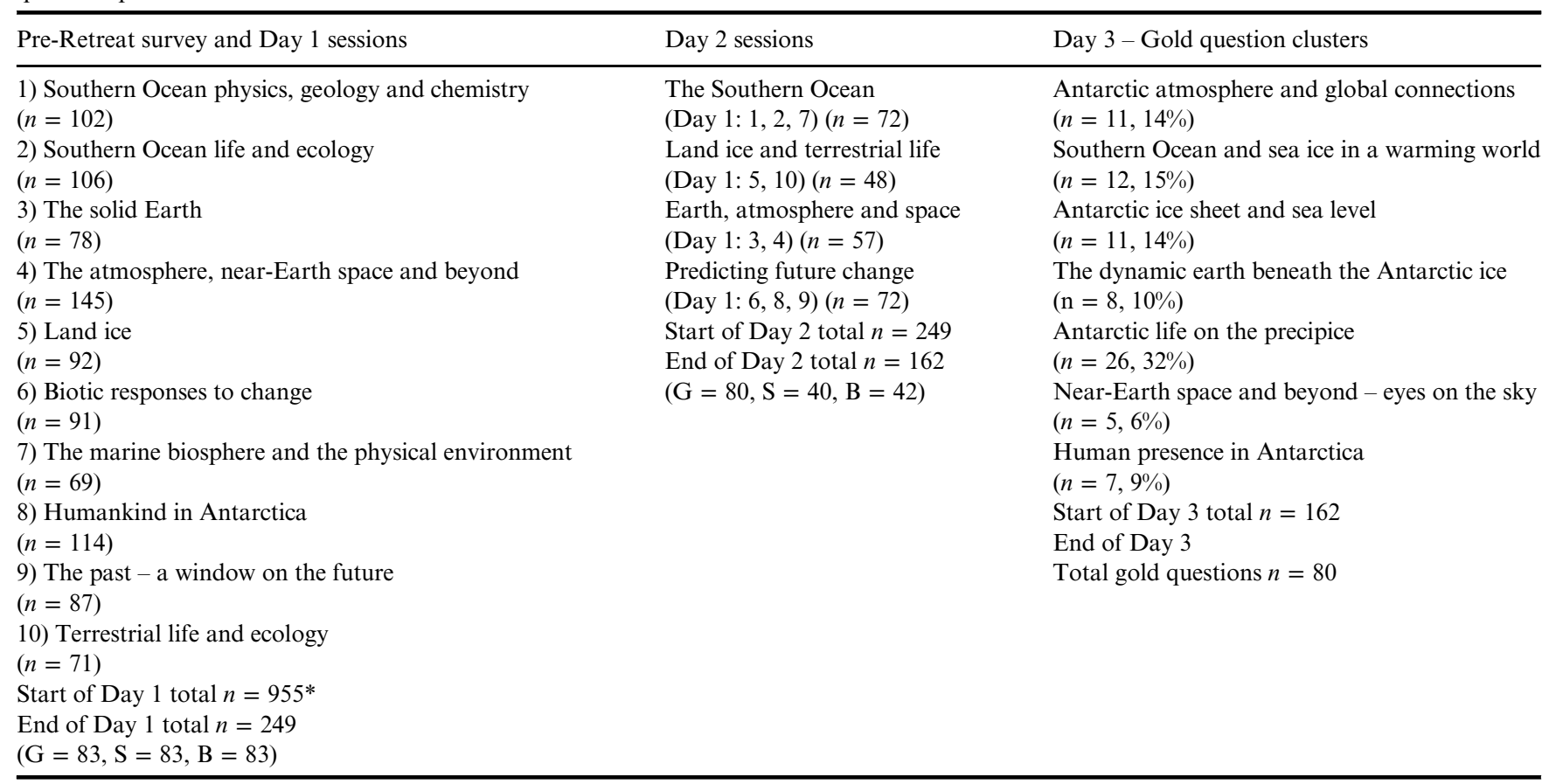

additional questions were added to the database by this process. In total, 955 questions were listed, including 60 placed under more than one topic. The results of the pre-Retreat voting were provided to the attendees prior to and during the Retreat.

\section{The Retreat and final question selection}

The Retreat occurred over four days and was designed to identify the key scientific questions, sufficient to describe the most important research priorities through a winnowing process of structured debate, discussion, revision and voting. The days were divided into discrete discussion sessions dealing with the questions. Each discussion session was managed by a discussion leader, an assisting discussion leader, and at least one technical assistant to record the outcomes and manage voting (Table S1). In advance of the Retreat a group of technical assistants was formed to develop and test the scan procedures. Prior to the first full day (Day 1) of the Retreat, training sessions were held on-site to ensure that the discussion leaders and technical assistants were conversant with these methods, tools and goals. At the beginning and the end of each day of the Retreat, attendees were assembled in plenary to gauge progress, answer questions and address issues that may have arisen.

The schedule for Day 1 included three 2-hour discussion sessions, each with three or four parallel sessions (Table I). In each Day 1 session, attendees: i) reviewed the voting outcomes from the pre-Retreat survey, ii) removed those questions with no or few votes (unless considered to have unrecognized merit that could be brought out by editing), iii) discussed the questions as a whole, and iv) if necessary, re-worded and/or merged similar or related questions. Once discussions ended, the remaining questions were ranked by vote into three categories as gold (most important), silver (very important) or bronze (important) (Sutherland et al. 2013). Each Day 1 session was allotted 24 total questions, eight in each of the three categories as a goal. One exception was 'the atmosphere, near-Earth space and beyond' session, which was allocated 11 questions per category due to the large number of initial questions. Questions that received the same number of votes equal to the lowest number of votes for retention were ranked by an additional vote on only those questions. If there was no consensus, all questions receiving the same number of votes were retained for further discussion. This process eliminated $74 \%$ of the initial questions leaving 249 questions for consideration on Day 2.

Day 2 of the Retreat included two 2-hour discussion sessions, each with two parallel, merged sessions (see Table I for the Day 1 sessions that were merged). A process similar to that used on Day 1 was repeated (pre-Retreat results were no longer relevant). To maintain balance amongst topics, each Day 2 session was allotted a 
target number of questions in the gold, silver and bronze categories proportionate to the number of combined Day 1 sessions (Table I). 'The Southern Ocean' and 'Predicting future change' sessions were allocated 24 questions per category and 'Land ice and terrestrial life' and 'Earth, atmosphere and space' were allocated 16 and 19 questions per category, respectively. In each session, the combined gold questions from Day 1 were examined to identify related or similar questions from the merged sessions and some, based on closer scrutiny and discussion, were either combined into a single question and retained in the gold category or re-classified as silver. The bronze questions were examined to identify ones that, with editing, might rise to the silver category. The decision to move questions from the bronze to the silver category was by vote. Questions in the silver category were then ranked by a vote to complete the allocation of gold questions. The remaining questions were categorized as silver or bronze based on the vote and the number of questions allotted to each category. This process eliminated $35 \%$ of the remaining Day 1 questions leaving a total of 162 questions for further consideration on Day 3.

On Day 3, the questions remaining from the Day 2 sessions were merged within the gold, silver and bronze categories for final consideration by all Retreat attendees in a single discussion session (Table I). The combined gold questions were examined to identify related or similar questions from the merged sessions and some, based on closer scrutiny and discussion, were either combined into a single question and retained in the gold category or re-classified as silver. The bronze questions were examined to identify ones that, with editing, might rise to the silver category. The decision to move questions from the bronze to silver category was decided by vote. Questions in the silver category were then ranked by the same voting procedure used on Day 2 to complete the allocation of gold questions, which was decided by vote to be 80 . This process eliminated $51 \%$ of the remaining Day 2 questions (Table I). The voting outcome was discussed, questions were edited where required, the final list of questions was agreed and the questions were clustered within a framework of topics (Table I).

\section{Question clusters and summaries}

Post-Retreat, the final questions were further edited for consistency and clarity, but the essence of the question was unchanged. Cluster titles were refined to better communicate the overarching themes (Table I). Questions were assigned consecutive numbers for ease of referencing but these numbers do not indicate relative importance or rank within or between clusters. Initial assignments of questions to clusters were reexamined to assess the logic of the sorting and compatibility with mainstream scientific classification schemes. In this process, it was recognized that some questions could be assigned to more than one cluster reflective of the crossdisciplinary nature of Antarctic and Southern Ocean science. Questions were assigned to the cluster most closely aligned with the primary focus and annotated as 'cross-cuts' with one or more of the other clusters.

Once the sorting of questions and naming of the clusters was agreed, cluster summaries were written in consultation with Retreat attendees via email. Summaries were in a standard format of a 500-word narrative describing the overarching theme and how questions were inter-related, a list of questions in the cluster and cross-cutting ones with notes explaining the significance of each question, and consideration of technological challenges and extraordinary logistical requirements to be addressed to answer the questions. All cross-cutting questions were listed in, and considered to be part of, the cluster summary. The summaries will be the basis for launching public forums to continue discussions of the scan outcomes, such as Wikis.

\section{Results}

The study of Antarctica and the Southern Ocean, and their roles in the Earth and climate system, provides critical insights into natural variability, the processes that govern global-scale change, and the influence of human activities on environmental change. The scan identified a wide range of high priority questions that, once answered, will substantially advance our understanding of: i) the Antarctic atmosphere, ocean, ice, the solid Earth and its living systems, ii) the interactions within and between Antarctic and global processes, iii) critical couplings, feedbacks and thresholds that modulate and regulate these interactions, iv) how Earth's polar regions have driven and responded to ongoing and past change, $v$ ) the relationships between ecological and evolutionary processes and their roles in structuring biodiversity and ecosystem service delivery, vi) the origins of the universe and life, vii) how the presence of humans in the region is changing and diversifying, and the ramifications of these changes for Antarctic governance regimes. These advances in understanding will also improve the reliability of integrated, predictive models over a range of spatial and temporal scales. The following sections describe the major themes identified by the scan and the 80 high priority questions (the Q.X notation refers to the horizon scan final question list presented in Tables II-V; a complete list is provided in Table S2).

\section{Antarctic atmosphere and global connections (Table II)}

Changes in Antarctica's atmosphere have the potential to alter the planetary energy budget, modulate the poleto-equator temperature gradient, modify the chemical composition of the atmosphere, and regulate large-scale 
Table II. Antarctic and Southern Ocean Science Horizon Scan questions in clusters 'Antarctic atmosphere and global connections' and 'Southern Ocean and sea ice in a warming world'.

\begin{tabular}{|c|c|c|c|}
\hline \multicolumn{2}{|r|}{ Antarctic atmosphere and global connections } & \multicolumn{2}{|r|}{ Southern Ocean and sea ice in a warming world } \\
\hline 1. & $\begin{array}{l}\text { How is climate change and variability in the high southern } \\
\text { latitudes connected to lower latitudes including the tropical }\end{array}$ & 12. & $\begin{array}{l}\text { Will changes in the Southern Ocean result in feedbacks that } \\
\text { accelerate or slow the pace of climate change? }\end{array}$ \\
\hline 2. & $\begin{array}{l}\text { ocean and monsoon systems? } \\
\text { How do Antarctic processes affect mid-latitude weather and } \\
\text { extreme events? }\end{array}$ & 13. & $\begin{array}{l}\text { Why are the properties and volume of Antarctic Bottom Water } \\
\text { changing, and what are the consequences for global ocean } \\
\text { circulation and climate? }\end{array}$ \\
\hline 3. & $\begin{array}{l}\text { How have teleconnections, feedbacks, and thresholds in decadal } \\
\text { and longer term climate variability affected ice sheet response } \\
\text { since the Last Glacial Maximum, and how can this inform } \\
\text { future climate projections? }\end{array}$ & 15 . & $\begin{array}{l}\text { How does Southern Ocean circulation, including exchange with } \\
\text { lower latitudes, respond to climate forcing? } \\
\text { What processes and feedbacks drive changes in the mass, } \\
\text { properties and distribution of Antarctic sea ice? }\end{array}$ \\
\hline 4. & $\begin{array}{l}\text { What drives change in the strength and position of westerly } \\
\text { winds, and what are their effects on ocean circulation, carbon } \\
\text { uptake and global teleconnections? }\end{array}$ & 16. & $\begin{array}{l}\text { How do changes in iceberg numbers and size distribution affect } \\
\text { Antarctica and the Southern Ocean? } \\
\text { How has Antarctic sea ice extent and volume varied over decadal }\end{array}$ \\
\hline 5. & $\begin{array}{l}\text { How did the climate and atmospheric composition vary prior to } \\
\text { the oldest ice records? }\end{array}$ & 18. & $\begin{array}{l}\text { to millennial timescales? } \\
\text { How will changes in ocean surface waves influence Antarctic sea }\end{array}$ \\
\hline 6. & $\begin{array}{l}\text { What controls regional patterns of atmospheric and oceanic } \\
\text { warming and cooling in the Antarctic and Southern Ocean? } \\
\text { (Cross-cuts 'Southern Ocean') }\end{array}$ & 19. & $\begin{array}{l}\text { ice and floating glacial ice? } \\
\text { How do changes in sea ice extent, seasonality and properties } \\
\text { affect Antarctic atmospheric and oceanic circulation? }\end{array}$ \\
\hline 7. & $\begin{array}{l}\text { How can coupling and feedbacks between the atmosphere and } \\
\text { the surface (land ice, sea ice and ocean) be better represented in } \\
\text { weather and climate models? (Cross-cuts 'Southern Ocean' and } \\
\text { 'Antarctic ice sheet') }\end{array}$ & 20. & $\begin{array}{l}\text { (Cross-cuts 'Antarctic atmosphere') } \\
\text { How do extreme events affect the Antarctic cryosphere and } \\
\text { Southern Ocean? (Cross-cuts 'Antarctic ice sheet') } \\
\text { How did the Antarctic cryosphere and the Southern Ocean }\end{array}$ \\
\hline 8. & $\begin{array}{l}\text { Does past amplified warming of Antarctica provide insight } \\
\text { into the effects of future warming on climate and ice sheets? } \\
\text { (Cross-cuts 'Antarctic ice sheet') }\end{array}$ & 22 & $\begin{array}{l}\text { contribute to glacial/inter-glacial cycles? (Cross-cuts 'Antarctic } \\
\text { ice sheet') } \\
\text { How will climate change affect the physical and biological uptake }\end{array}$ \\
\hline 9. & $\begin{array}{l}\text { Are there } \mathrm{CO}_{2} \text { equivalent thresholds that foretell collapse of all or } \\
\text { part of the Antarctic ice sheet? (Cross-cuts 'Antarctic ice sheet') }\end{array}$ & 23. & $\begin{array}{l}\text { of } \mathrm{CO}_{2} \text { by the Southern Ocean? (Cross-cuts 'Antarctic life') } \\
\text { How will changes in freshwater inputs affect ocean circulation }\end{array}$ \\
\hline 10. & $\begin{array}{l}\text { Will there be release of greenhouse gases stored in Antarctic and } \\
\text { Southern Ocean clathrates, sediments, soils and permafrost as } \\
\text { climate changes? (Cross-cuts 'Dynamic Earth') }\end{array}$ & & and ecosystem processes? (Cross-cuts 'Antarctic life') \\
\hline 11. & $\begin{array}{l}\text { Is the recovery of the ozone hole proceeding as expected and how } \\
\text { will its recovery affect regional and global atmospheric } \\
\text { circulation, climate and ecosystems? (Cross-cuts 'Antarctic life' } \\
\text { and 'Human') }\end{array}$ & & \\
\hline
\end{tabular}

Questions are assigned numbers for ease of referencing and do not indicate relative importance or rank-order within or between clusters.

Questions that cross-cut clusters are indicated with red italics.

variability in atmospheric circulation. The atmosphere also moderates energy and mass transfers between the ocean, sea ice, land and biota in the southern polar region and elsewhere. Two-way interactions between the Antarctic and lower latitude atmosphere have the potential to influence global weather patterns and climate, with forcing from lower latitudes on Antarctic climate already being well documented (e.g. Ding et al. 2011, Bromwich et al. 2013, Li et al. 2014).

The processes that connect the Antarctic atmosphere to the mid- and lower latitudes remain largely undescribed. For example, the influence of climate change and variability at high southern latitudes on lower latitude phenomena in the tropical ocean and the monsoon system need better definition (Q.1). How changes and variability in Antarctica's climate might be expected to affect the frequency and intensity of extreme events, in Antarctica and beyond, is also unclear (Q.2). Better definition of present-day controls on the strength of circumpolar westerly winds and regional warming will clarify how continued warming will impact oceanic $\mathrm{CO}_{2}$-uptake and overturning circulation (Q.4 and Q.6) (Meredith et al. 2012). Coupling and feedbacks at interfaces between the atmosphere and land ice, sea ice and the ocean need to be more accurately portrayed in weather and climate models (Q.7). On local scales this atmosphere-surface coupling is driven by radiative fluxes, influenced by clouds and radiatively active gases, and turbulent fluxes, driven by boundary layer processes. Changes in the surface state, such as changing sea surface temperature, sea ice extent, seasonality, concentration, and thickness or melting of snow and ice surfaces also modulate this exchange. On larger scales, surface coupling is influenced by atmospheric teleconnections and large-scale changes in sea ice and ocean state. It is unclear whether greenhouse gas reservoirs in southern polar clathrates, sediments, soils and permafrost will be released as the region warms and how this release might feedback to the climate system (Q.10). Atmospheric waves are widespread and have the potential to impact atmospheric dynamics, atmospheric chemistry 
and cloud formation. The mechanisms that lead to the generation of waves, their vertical and horizontal propagation in the atmosphere, and their impact on the state of the atmosphere require additional study (Q.73).

The effect of temporal and spatial variability in sea ice thickness and extent on atmospheric circulation is unknown (Q.19). The influence of large-scale atmospheric and oceanic processes on the melting of ice shelves and ice sheet margins is likewise ill-defined (Q.31). Clearer delineation of the relationship between atmospheric greenhouse gas concentrations and Antarctic ice sheet stability is needed if important thresholds are to be recognized (Q.9). Understanding the interplay of planetary ice and tectonic history is also important for determining the effect of altered atmospheric compositions on the Earth's radiation budget and climate over time (Q.38).

Recent studies suggest that over the last half of the Twentieth Century the impact of ozone depletion was roughly 2-3-times larger than that associated with increasing greenhouse gases for Southern Hemisphere tropospheric circulation (Polvani et al. 2011). This raises questions about how ozone recovery and continued increases in greenhouse gases will affect regional and global atmospheric circulation and climate (Q.11). The role of space weather, its impacts on the ionosphere and connections to the global atmosphere need to be better understood to improve predictions (Q.72). How organisms and ecosystems will respond to atmospheric warming, extreme events and pollutants is also poorly understood (Q.11, Q.45, Q.53 and Q.63).

Studies of palaeoclimates will provide critical data for evaluating climate models under a range of greenhouse gas forcing scenarios. Critical knowledge gaps will be addressed by studying climate variability, teleconnections, feedbacks and thresholds since the Last Glacial Maximum, during past amplified warming of Antarctica, and climate and atmospheric composition variability in periods that pre-date ice core records ( $>1$ million years ago) (Q.3, Q.5 and Q.8).

Many of these atmospheric and related phenomena are only partially characterized. Observational, process and palaeoclimate studies will improve current understanding of the details of these interactions and enable better representation of Antarctic atmospheric processes in, and improve the reliability of, climate models. A clearer differentiation of natural variability and anthropogenic forcing of climate change is essential if the role of humans in influencing climate is to be confidently determined (Q.74).

\section{Southern Ocean and sea ice in a warming world (Table II)}

Southern Ocean processes influence climate and biogeochemical cycles on global scales. For example, the region south of $40^{\circ} \mathrm{S}$ is responsible for $c .40 \%$ of the oceanic uptake of anthropogenic $\mathrm{CO}_{2}$ (Khatiwala et al. 2013) and has been responsible for more than $50 \%$ of the increase in ocean heat content over the past 50 years (Levitus et al. 2012). Nutrients exported from the Southern Ocean to lower latitudes support $75 \%$ of ocean primary productivity north of $30^{\circ} \mathrm{S}$ (Sarmiento et al. 2003). The Southern Ocean has also played a major role in glacial/inter-glacial transitions by transferring $\mathrm{CO}_{2}$ from the deep ocean to the atmosphere (Jaccard et al. 2013). These global influences arise in large part from the uniqueness of Southern Ocean circulation patterns. The Antarctic Circumpolar Current connects the world ocean basins (Rintoul 2011), while the overturning circulation links the deep and shallow layers of the ocean (Marshall \& Speer 2012). These connections establish a global-scale circulation that sets the capacity of the ocean to store heat and $\mathrm{CO}_{2}$ affecting climate.

The seasonal formation and melt of a vast area of Antarctic sea ice strongly influences global climate and Southern Ocean ecosystems (Massom \& Stammerjohn 2010). The formation of Antarctic sea ice drives ocean circulation through the production of dense, salty, cold water. The presence of sea ice alters the Earth's albedo and modulates the exchange of heat, momentum and gases between the ocean and atmosphere. Sea ice influences water column light penetration and nutrient concentrations in the upper ocean and, hence, biological productivity. Sea ice also provides an essential habitat for a wide range of organisms (Thomas \& Dieckmann 2010). The ocean and sea ice are coupled to glacial ice around the margins of Antarctica. For example, ocean heat flux (itself influenced by sea ice) drives glacial melt, while glacial meltwater, in turn, affects ocean circulation and sea ice distribution (Bintanja et al. 2013).

The fundamental role of the Southern Ocean and sea ice in the Earth system suggests that warming in the region will have global consequences. Our understanding of the drivers and impacts of Southern Ocean and sea ice change remains incomplete, limiting our ability to predict the course of future change. Growing evidence suggest that the Southern Ocean and its sea ice cover have changed in recent decades. The ocean has warmed, freshened and acidified, and fronts have migrated, altering habitats (Böning et al. 2008, Gille 2008, Sokolov $\&$ Rintoul 2009). Sea ice has contracted in some areas while expanding in others, resulting in a net increase in overall extent (Stammerjohn et al. 2012, Holland 2014). The Antarctic ice sheet has lost mass in response to the thinning of ice shelves due to increased ocean water heat flux (Pritchard et al. 2012). The sensitivity of the Southern Ocean overturning circulation to climate variability and change is not well understood (Q.14). Changes in the circulation of the Southern Ocean may result in feedbacks that accelerate or slow the pace of climate change, but the likelihood and importance of such feedbacks is largely unknown (Q.12 and Q.22). The recent changes in the properties and volume of Antarctic Bottom Water (Q.13) 
Table III. Antarctic and Southern Ocean Science Horizon Scan questions in clusters 'Antarctic ice sheet and sea level' and 'Dynamic earth - probing beneath Antarctic ice'.

\begin{tabular}{|c|c|}
\hline \multicolumn{2}{|r|}{ Antarctic ice sheet and sea level } \\
\hline 24. & $\begin{array}{l}\text { How does small-scale morphology in subglacial and continental } \\
\text { shelf bathymetry affect Antarctic ice sheet response to changing } \\
\text { environmental conditions? (Cross-cuts 'Dynamic Earth') }\end{array}$ \\
\hline 25. & $\begin{array}{l}\text { What are the processes and properties that control the form and } \\
\text { flow of the Antarctic ice sheet? }\end{array}$ \\
\hline 26. & $\begin{array}{l}\text { How does subglacial hydrology affect ice sheet dynamics, and how } \\
\text { important is it? (Cross-cuts 'Dynamic Earth') }\end{array}$ \\
\hline 27. & $\begin{array}{l}\text { How do the characteristics of the ice sheet bed, such as geothermal } \\
\text { heat flux and sediment distribution, affect ice flow and ice sheet } \\
\text { stability? (Cross-cuts Dynamic Earth') }\end{array}$ \\
\hline 28. & $\begin{array}{l}\text { What are the thresholds that lead to irreversible loss of all or part of } \\
\text { the Antarctic ice sheet? }\end{array}$ \\
\hline 29. & $\begin{array}{l}\text { How will changes in surface melt over the ice shelves and ice sheet } \\
\text { evolve, and what will be the impact of these changes? }\end{array}$ \\
\hline 30. & $\begin{array}{l}\text { How do oceanic processes beneath ice shelves vary in space and } \\
\text { time, how are they modified by sea ice, and do they affect ice loss } \\
\text { and ice sheet mass balance? (Cross-cuts 'Southern Ocean') }\end{array}$ \\
\hline 31. & $\begin{array}{l}\text { How will large-scale processes in the Southern Ocean and } \\
\text { atmosphere affect the Antarctic ice sheet, particularly the rapid } \\
\text { disintegration of ice shelves and ice sheet margins? (Cross-cuts } \\
\text { 'Antarctic atmosphere' and 'Southern Ocean') }\end{array}$ \\
\hline 32. & $\begin{array}{l}\text { How fast has the Antarctic ice sheet changed in the past and what } \\
\text { does that tell us about the future? }\end{array}$ \\
\hline 33. & $\begin{array}{l}\text { How did marine-based Antarctic ice sheets change during previous } \\
\text { inter-glacial periods? }\end{array}$ \\
\hline 34. & $\begin{array}{l}\text { How will the sedimentary record beneath the ice sheet inform } \\
\text { our knowledge of the presence or absence of continental ice? } \\
\text { (Cross-cuts 'Dynamic Earth') }\end{array}$ \\
\hline
\end{tabular}

Dynamic Earth - probing beneath Antarctic ice

35. How does the bedrock geology under the Antarctic ice sheet inform our understanding of supercontinent assembly and break-up through Earth's history?

36. Do variations in geothermal heat flux in Antarctica provide a diagnostic signature of sub-ice geology?

37. What is the crust and mantle structure of Antarctica and the Southern Ocean, and how do they affect surface motions due to glacial isostatic adjustment?

38. How does volcanism affect the evolution of the Antarctic lithosphere, ice sheet dynamics, and global climate? (Cross-cuts 'Antarctic atmosphere' and 'Antarctic ice sheet')

39. What are and have been the rates of geomorphic change in different Antarctic regions, and what are the ages of preserved landscapes?

40. How do tectonics, dynamic topography, ice loading and isostatic adjustment affect the spatial pattern of sea level change on all timescales? (Cross-cuts 'Antarctic ice sheet')

41. Will increased deformation and volcanism characterize Antarctica when ice mass is reduced in a warmer world, and if so, how will glacial- and ecosystems be affected? (Cross-cuts 'Antarctic life')

42. How will permafrost, the active layer and water availability in Antarctic soils and marine sediments change in a warming climate, and what are the effects on ecosystems and biogeochemical cycles? (Cross-cuts 'Antarctic life')

Questions are assigned numbers for ease of referencing and do not indicate relative importance or rank-order within or between clusters.

Questions that cross-cut clusters are indicated with red italics.

remain unexplained. Understanding of the processes controlling the mass, properties and distribution of Antarctic sea ice (Q.15 and Q.18) and its interaction with the atmosphere and ocean is inadequate to predict future conditions with confidence (Q.6, Q.7, Q.19 and Q.20).

Better knowledge of how Southern Ocean circulation and sea ice have varied in the past, on timescales from decadal to glacial cycles, will provide a perspective on the response of the system to future forcing (Q.17 and Q.21). Altered freshwater input from glacial melt, icebergs and precipitation may have widespread consequences for the atmosphere, ocean, cryosphere and associated ecosystems (Q.16 and Q.23). The influence of oceanic and atmospheric processes on floating ice shelves must be better understood to assess the future of the Antarctic ice sheet and sea level rise (Q.30 and Q.31). The responses of marine ecosystems to past (Q.45) and future changes in ocean circulation and acidification, seasonality and stratification are poorly known (Q.60 and Q.65).

\section{Antarctic ice sheet and sea level (Table III)}

The vast volume of water encased in the Antarctic ice sheet has the greatest potential on the planet to dramatically raise global sea levels. For several thousand years, an amount of snow equivalent to $6 \mathrm{~mm}$ of global sea level has fallen annually on the ice sheet, and a similar amount has been returned annually to the oceans through basal melting of floating ice and iceberg calving. However, an increasing imbalance in this mass budget has been observed in the past two decades, and the trend is accelerating (Joughin \& Alley 2011, Rignot et al. 2011, Pritchard et al. 2012, Shepherd et al. 2012, Mouginot et al. 2014). Predictions of future ice loss are dependent on ice sheet evolution models which can only be improved by more accurate measurement of ice sheet features, and variability in time and space. The Antarctic ice sheet system is complex in its internal dynamics, and sensitivities to atmospheric and oceanic forcings.

Improved understanding of the processes and ice properties that control the form and flow of ice sheets will be critical to improve models (Q.25). Oceanic processes occurring beneath ice shelves remain largely uncharacterized (Q.30). The effects of large-scale changes in the oceanic and atmospheric forcing on ice sheet stability require better characterization (Q.31). Thresholds in forcing that lead to irreversible loss of all or part of the ice sheet need better definition (Q.28) (Joughin et al. 2014, Rignot et al. 2014). 
Improving the reliability of decadal- to centennial-scale ice sheet behaviour predictions will be essential for predicting sea level rise. The observational record is short and the key processes that control Antarctic ice mass loss that are poorly understood include ice-ocean interactions, the role of surface melt, small-scale morphology in bedrock topography and coastal bathymetry, geothermal heat flux, sediment characteristics and distributions, and subglacial hydrology (Q.24, Q.26, Q.27 and Q.29). The Antarctic continent beneath the ice sheet remains largely unexplored and its properties are poorly known. A more thorough understanding of how ice sheets have responded to past climate change and how marine-based ice sheets responded during previous inter-glacial periods and past amplified warming of Antarctica will improve predictions of the response of the Antarctic ice sheet to a warming world (Q.28, Q.32 and Q.33). Sediment records beneath the ice in the interior of Antarctica will provide unique records of the presence or absence of continental ice over geologic time (Q.34).

\section{Dynamic Earth - probing beneath Antarctic ice (Table III)}

The deep-time chronicle of earth preserved in continental bedrock provides evidence of a changing plate tectonic engine, the evolution of life, and the history of planetary ice. Antarctica has played a central role in the evolution of the solid Earth and contains an ancient rock record of the assembly and dispersal of multiple supercontinents, repeated ice ages, and the global distribution of biota across space and time. Antarctica was the keystone of Gondwana and older supercontinents, but the history of its collision and rifting is yet to be fully revealed and linked with formerly neighbouring continents (Dalziel 2013, Harley et al. 2013). Continental break-up and intra-plate rifting are associated with extensive magmatism in some areas of Antarctica (Elliot \& Fleming 2004, Rocchi et al. 2005, Storey et al. 2013).

Decoding the history of the geological terranes hidden beneath Antarctic ice is essential to understanding how supercontinents assemble and break apart (Q.35), and how mantle plumes may drive continental break-up (Q.38). The Antarctic deep-time fossil record, throughout the changing configurations of supercontinents, provides critical insights into biological evolution and extinction patterns in response to global events and changing palaeoclimates (Q.46) (Francis et al. 2008). In particular, Antarctic fossil assemblages demonstrate how both marine and terrestrial ecosystems from the continent and surrounding oceans responded to past warm, high- $\mathrm{CO}_{2}$ climates in southern high latitudes (Q.45). During more recent glacial periods, the presence of refugia would have been crucial for the survival of life in Antarctica.

Solid earth processes intersect with the evolution of climate, ice sheets and life. Global evidence points to a fundamental role for extensive volcanism in climate change (Timmreck 2012). Climate change and solid earth properties linked with volcanism, such as geothermal flux, influence biotic distributions (Fraser et al. 2014). Volcanism may affect ice sheet dynamics (Vogel \& Tulaczyk 2006, Corr \& Vaughan 2008). The extent and timing of past volcanism in Antarctica, now concealed, must be documented to better understand its effects on the lithosphere, ice sheets and climate (Q.38). Volcanism and seismicity may be triggered by changing ice sheet mass (Stewart et al. 2000, Sigmundsson et al. 2010, Tuffen 2013) and vertical displacements of Earth's surface due to ice load fluctuations may influence ice sheet stability (Gómez et al. 2010). Antarctica currently has ongoing magmatism beneath the ice sheets (Lough et al. 2013), rapid uplift is already underway where recent ice loss has occurred and the underlying deep mantle is mechanically weak (Groh et al. 2012, Nield et al. 2014). An improved understanding of crust and mantle properties (Q.37), and development of models for Earth deformation and volcanic activity as the ice sheet changes in the future (Q.41) are required to better constrain future trends in volcanism and crustal deformation.

The link between dynamic earth processes and ice sheets is especially important in Antarctica. Tectonics and surface processes control the formation of mountain peaks where ice sheets first grow (DeConto \& Pollard 2003), the basins where their products are deposited (Naish et al. 2009) and the extent of continental terrain available to host ice sheets (Wilson et al. 2012). The strength of the crust and mantle control how the Earth responds to ice loads (Geruo et al. 2013). Subglacial morphology and geological structure (Q.26) are primary influences on ice dynamics and subglacial hydrological regimes (Schoof \& Hewitt 2013). High-resolution continent-wide mapping of topography and geological architecture, and sampling of bedrock and basins beneath the ice, are essential for next-generation coupled climate-ice sheet models (Q.32). Geothermal heat flux, virtually unknown across Antarctica (Shapiro \& Ritzwoller 2004, Carson et al. 2014), is a key control on ice behaviour and subglacial hydrology (Q.27) (Llubes et al. 2006) and may indicate the age and extent of crustal terranes and sedimentary basins (Q.36).

Remarkable ancient landscapes beneath ice cover reveal the history of interactions between ice and the solid earth (Jamieson et al. 2010, Rose et al. 2013, Thomson et al. 2013). Dating these landscapes using emerging techniques will lead to new paradigms on both landscape history and surface processes (Q.39). Understanding erosion processes and rates of geomorphological change across the subglacial terrain will enable scientists to decipher feedbacks between tectonic surface displacement, global climate and, critically, the growth and demise of ice sheets. Relative sea level records provide historical data on ice mass change 
Table IV. Antarctic and Southern Ocean Science Horizon Scan questions in cluster 'Antarctic life on the precipice'.

Antarctic life on the precipice

43. What is the genomic basis of adaptation in Antarctic and Southern Ocean organisms and communities?

44. How fast are mutation rates and how extensive is gene flow in the Antarctic and the Southern Ocean?

45. How have ecosystems in the Antarctic and the Southern Ocean responded to warmer climate conditions in the past? (Cross-cuts 'Antarctic atmosphere' and 'Oceans')

46. How has life evolved in the Antarctic in response to dramatic events in the Earth's history? (Cross-cuts 'Dynamic Earth')

47. How do subglacial systems inform models for the development of life on Earth and elsewhere? (Cross-cuts 'Eyes on the sky')

48. Which ecosystems and food webs are most vulnerable in the Antarctic and Southern Ocean, and which organisms are most likely to go extinct?

49. How will threshold transitions vary over different spatial and temporal scales, and how will they impact ecosystem functioning under future environmental conditions?

50. What are the synergistic effects of multiple stressors and environmental change drivers on Antarctic and Southern Ocean biota?

51. How will organism and ecosystems respond to a changing soundscape in the Southern Ocean?' (Cross-cuts 'Human')

52. How will next-generation contaminants affect Antarctic and Southern Ocean biota and ecosystems?

53. What is the exposure and response of Antarctic organisms and ecosystems to atmospheric contaminants (e.g. black carbon, mercury, sulfur, etc.), and are the sources and distributions of these contaminants changing? (Cross-cuts 'Antarctic atmosphere' and 'Human')

54. How will the sources and mechanisms of dispersal of propagules into and around the Antarctic and Southern Ocean change in the future?
55. How will invasive species and range shifts of indigenous species change Antarctic and Southern Ocean ecosystems? (Cross-cuts 'Human')

56. How will climate change affect the risk of spreading emerging infectious diseases in Antarctica? (Cross-cuts 'Human')

57. How will increases in the ice-free Antarctic intertidal zone impact biodiversity and the likelihood of biological invasions?

58. How will climate change affect existing and future Southern Ocean fisheries, especially krill stocks? (Cross-cuts 'Human')

59. How will linkages between marine and terrestrial systems change in the future?

60. What are the impacts of changing seasonality and transitional events on Antarctic and Southern Ocean marine ecology, biogeochemistry and energy flow?

61. How will increased marine resource harvesting impact Southern Ocean biogeochemical cycles? (Cross-cuts 'Human')

62. How will deep sea ecosystems respond to modifications of deep water formation, and how will deep sea species interact with shallow water ecosystems as the environment changes?

63. How can changes in the form and frequency of extreme events be used to improve biological understanding and forecasting? (Cross-cuts 'Antarctic atmosphere')

64. How can temporal and spatial 'omic-level' analyses of Antarctic and Southern Ocean biodiversity inform ecological forecasting?

65. What will key marine species tell us about trophic interactions and their oceanographic drivers such as future shifts in frontal dynamics and stratification?

66. How successful will Southern Ocean Marine Protected Areas be in meeting their protection objectives, and how will they affect ecosystem processes and resource extraction? (Cross-cuts 'Human')

67. What ex situ conservation measures, such as genetic repositories, are required for the Antarctic and Southern Ocean? (Cross-cuts 'Human')

68. How effective are Antarctic and Southern Ocean conservation measures for preserving evolutionary potential? (Cross-cuts 'Human')

Questions are assigned numbers for ease of referencing and do not indicate relative importance or rank-order within or between clusters.

Questions that cross-cut clusters are indicated with red italics.

indicating when and where ice has been lost (Q.40). Contemporary changes in bedrock elevation provide a critical proxy record of both past and modern ice mass change (Q.40), modulated by tectonics and the strength of the crust and mantle (Q.37). Archives in rocks deposited in subglacial and proximal marine basins since the development of continental-scale Antarctic glaciation c. 34 million years ago (Q.34) will provide crucial deeptime records to validate model predictions of climate, ice sheet and sea level change (Naish et al. 2009, Bowman et al. 2013, Cook et al. 2013b, DeSantis et al. 2009). Documenting the status of permafrost (Q.42) in a warming world (Bockheim et al. 2013) will better define influences on the availability of water in terrestrial ecosystems (Smith et al. 2014) and the potential for release of greenhouse gases (Q.10) (DeConto et al. 2012, Wadham et al. 2012, 2013).

\section{Antarctic life on the precipice (Table IV)}

Antarctic living systems have long been thought of as generally simple and species poor, post-glacial, and exceptionally isolated, residing at the low end of the Earth's latitudinal diversity gradient. Over the last decade, a very different picture of the region's biota is emerging. Several taxa and ecosystems, for example those in the deep sea (Brandt et al. 2007) and elsewhere (Clarke \& Johnston 2003, Cary et al. 2010), are highly diverse. Regional and global connectivity is greater than supposed (Brandt et al. 2007), and molecular studies have revealed long histories of continental occupancy (Fraser et al. 2012). Antarctic living systems nonetheless occupy a region characterized by environmental extremes typically stressful to life. Temperatures are low, seasonality is pronounced, disturbance is common, and environments are exceptionally patchy (Cary et al. 2010, Rogers et al. 2012b, Gutt et al. 2013, Fraser et al. 2014). Although life has clearly adapted to these conditions (Rogers et al. 2012a), the basis of this adaptation at the genomic, molecular and cellular levels, the rates of evolution in the region compared with elsewhere, and how the spatial arrangement of populations affects evolutionary and ecological change remain poorly known (Q.43 and Q.44). 
Antarctic taxa are rarely involved in global analyses of evolutionary rate variation (Convey et al. 2014), despite the fundamental scientific insights that doing so will bring. Although variation in diversity among groups is appreciated, fresh perspectives are required to understand the role of past events and to elucidate the drivers of diversification that underlie such variation. These include investigation of past events in the Earth's history, and modern 'omic' and ecological approaches (Q.45, Q.46 and Q.47). Such understanding, as well as that obtained from investigating the relative roles of phenotypic plasticity and among-generational change (Gutt et al. 2012), is also important for forecasting individual and population-level responses to modern environmental change (Q.11, Q.48, Q.58 and Q.63). Such change impacts diversity, and genomic and food resources (Tin et al. 2009, Chown et al. 2012b, Turner et al. 2013).

In Antarctic marine systems, environmental change drivers include changing climates, sea ice and wind conditions, ocean acidification, increasing resource exploitation, pollution and the threat of biological invasions, and in turn will have important impacts on key processes such as $\mathrm{CO}_{2}$ uptake (Q.22, Q.23, Q.52, Q.54, Q.57, Q.60, Q.61 and Q.65). Connections between shallower water and deep sea species and ecosystems, and the effect of modifications of deep water formation and environmental change on these interactions are poorly understood (Q.62). For terrestrial systems, the drivers include climate change, the impacts of invasive alien species, local pollution and increasing human impacts (Q.52, Q.53 and Q.54). Changing infectious disease risks are important in both systems (Kerry \& Riddle 2009), and for humans, but these risks and their consequences are little investigated (Q.56 and Q.80).

While studies of the outcomes of single change drivers are underway, investigations of interactions among them are uncommon (Byrne \& Przeslawski 2013). Nonetheless, it is clear that environments seldom vary in a simple way, and that many kinds of environmental change are simultaneously taking place. Investigating such interactions is complicated by the difficulty of the large experiments required. New techniques will be needed to overcome these limitations (Q.50 and Q.64). Because many systems have thresholds, which are often irreversible (Barnosky et al. 2012), incorporating forecasts of when such thresholds may be reached, especially in response to extreme events, is a critical requirement for future work (Q.49 and Q.63). Little is known about how crossing these thresholds might affect Antarctic biodiversity and its increasing importance as a valuable resource for human livelihoods.

Likewise, knowledge is scant about how changing physical conditions, such as permafrost on land, sea ice change in the intertidal and deep water formation, might affect biodiversity, or whether some taxa may be used as indicators of the impacts of these changes (Q.42, Q.62 and Q.65). Major marine monitoring programmes currently rely on specific species as biological indicators, but among these species variable and incongruent responses are already clear (Constable et al. 2014). The mechanisms that underlie these trends and how they relate to other taxa and ecosystems are unknown. Management responses, to secure the biodiversity and resources of the region are dependent on such information. Conservation management actions also depend on other knowledge, such as being able to distinguish range shifts from anthropogenic introductions in marine and terrestrial systems (Chown et al. 2012a) (Q.55 and Q.66). Genetic repositories and similar ex situ conservation measures will serve critical roles in defining and preserving existing biodiversity (Q.67), though they are little explored in the region. Conservation approaches to secure evolutionary

Table V. Antarctic and Southern Ocean Science Horizon Scan questions in clusters 'Near-Earth space and beyond - eyes on the sky' and 'Human presence in Antarctica'.

\begin{tabular}{|c|c|c|c|}
\hline \multicolumn{2}{|r|}{ Near-Earth space and beyond - eyes on the sky } & \multicolumn{2}{|r|}{ Human presence in Antarctica } \\
\hline $\begin{array}{l}69 . \\
70 .\end{array}$ & $\begin{array}{l}\text { What happened in the first second after the universe began? } \\
\text { What is the nature of the Dark Universe and how is it } \\
\text { affecting us? }\end{array}$ & 74. & $\begin{array}{l}\text { How can natural and human-induced environmental changes be } \\
\text { distinguished, and how will this knowledge affect Antarctic } \\
\text { governance? (Cross-cuts all other clusters) }\end{array}$ \\
\hline 71. & $\begin{array}{l}\text { What are the differences in the inter-hemispheric conjugacy } \\
\text { between the ionosphere and that in the lower, middle and }\end{array}$ & 75. & $\begin{array}{l}\text { What will be the impacts of large-scale, direct human modification of } \\
\text { the Antarctic environment? (Cross-cuts 'Antarctic life') }\end{array}$ \\
\hline & upper atmospheres, and what causes those differences? & 76. & How will external pressures and changes in the geopolitical \\
\hline 72. & $\begin{array}{l}\text { How does space weather influence the polar ionosphere and } \\
\text { what are the wider implications for the global atmosphere? } \\
\text { (Cross-cuts 'Antarctic atmosphere') }\end{array}$ & 77. & $\begin{array}{l}\text { configurations of power affect Antarctic governance and science? } \\
\text { How will the use of Antarctica for peaceful purposes and science be } \\
\text { maintained as barriers to access change? }\end{array}$ \\
\hline 73. & $\begin{array}{l}\text { How do the generation, propagation, variability and } \\
\text { climatology of atmospheric waves affect atmospheric }\end{array}$ & 78. & $\begin{array}{l}\text { How will regulatory mechanisms evolve to keep pace with Antarctic } \\
\text { tourism? }\end{array}$ \\
\hline & $\begin{array}{l}\text { processes over Antarctica and the Southern Ocean? } \\
\text { (Cross-cuts 'Antarctic atmosphere') }\end{array}$ & $\begin{array}{l}79 . \\
80 .\end{array}$ & $\begin{array}{l}\text { What is the current and potential value of Antarctic ecosystem services? } \\
\text { How will humans, diseases and pathogens change, impact and adapt to } \\
\text { the extreme Antarctic environment? (Cross-cuts 'Antarctic life') }\end{array}$ \\
\hline
\end{tabular}

Questions are assigned numbers for ease of referencing and do not indicate relative importance or rank-order within or between clusters.

Questions that cross-cut clusters are indicated with red italics. 
potential are similarly underexplored though important (Q.68). To date, much management action has dealt separately with the marine and terrestrial environments, as a consequence both of political convenience and of a lack of evidence about the changing links between these systems. Future action will require tighter integration of understanding and management (Q.59, Q.74 and Q.75).

\section{Near-Earth space and beyond - eyes on the sky (Table V)}

Looking outward into space from Antarctica holds the promise of answering long-standing cosmological questions about our place in the universe and whether we are alone. Antarctica offers a unique vantage point from which to observe space, ranging from the upper levels of the atmosphere to the edge of the universe. Astrophysical observations require minimum interference from the Earth's atmosphere; low thermal background, low absorption and high angular resolution. Programmes that benefit most from these conditions are those aimed at understanding the overarching processes in the universe, from the origin of structure in the first few moments after the Big Bang (Q.69), through the nature of dark matter (Q.70) and the evolution of galaxies, to the birth and life-cycle of stars, and the formation of planetary systems around those stars. Antarctic observatories can be justified only for science that cannot be done cost-effectively, or at all, from lower latitude locations.

The Antarctic plateau is the only place on Earth where space observations at terahertz frequencies can be efficiently conducted (Yang et al. 2010), and blue ice areas are ideal for meteorite collection where ice flow and ablation bring them to the surface (Harvey 2003). Experiments already deployed at the South Pole, on the Antarctic high-plateau and as balloon payloads have demonstrated the advantages of observing space from Antarctica (Burton 2010). Key understanding of many aspects about the birth of the universe has come from Cosmic Microwave Background observations from the South Pole and McMurdo Stations (De Bernardis et al. 2000, Hanson et al. 2013, Ade et al. 2014). Dark matter makes up some $27 \%$ of the universe, while dark energy represents another $69 \%$. 'Normal' matter makes up the remaining 4\%, although even this includes ultra-high energy particles whose origin is unknown (Hoover et al. 2010). Identifying the origin of neutrinos is yet another puzzle (Aartsen et al. 2013). Unravelling the mysteries of the Dark Universe is one of the Twenty-first Century's most intriguing challenges (Q.70). Twenty years ago, no planets were known outside the solar system. As of May 2014, over 1700 planets around other stars have been confirmed (NASA 2014). In 20 years' time, studies of the atmospheric composition of these extra-solar planets should be routine and a major goal is detection of the presence of extra-terrestrial life. The diversity and evolution of Antarctic life may hold clues to the existence of life elsewhere in the universe and how best to unequivocally detect it (Q.47).

Conditions in interplanetary space, and how changes in this environment affect Earth's upper atmosphere, are known as 'space weather'. Inter-hemispheric conjugacy is the simultaneous response of magnetically paired regions of the Earth's two hemispheres to external forcing. Understanding this phenomenon in the polar regions remains a challenge. The extent to which conjugacy varies throughout the upper regions of the atmosphere is unknown (Q.71). The polar regions are particularly susceptible to the effects of space weather, as mass, momentum and energy of the solar wind are funnelled down the Earth's magnetic field lines. Understanding how the solar wind affects the polar upper atmosphere, and how these effects propagate around the globe, is a pressing scientific challenge with significant financial implications (Q.72). Upper atmospheric disturbances have the potential to disrupt communications, GPS navigation and electrical power systems. Therefore, a capability to predict space weather, and its impact, is vital (Baker et al. 2012).

Atmospheric waves range in scale from localized disturbances to planetary-scale waves (e.g. Rossby waves; Lanzerotti \& Park 2013). They include predictable phenomena, such as atmospheric tides, and one-off events as a result of, for example, earthquakes. Understanding the effect that waves generated in the polar regions have on the rest of the globe is crucial to the further development of global climate models (Q.73).

\section{Human presence in Antarctica (Table V)}

The presence of humans in the Antarctic region is multifaceted. While human impacts are well understood in some contexts (Frenot et al. 2005, Tin et al. 2009, Klein et al. 2014), in others they are not as well characterized. Human activities far removed from Antarctica also have an influence on the Antarctic environment, including ozone depletion (Q.11), climate warming (various Qs) and atmospheric transport of pollutants (Q.52 and Q.53). Indications are that human presence in the Antarctic will increase and diversify in the next two decades (Chown et al. 2012b, Woehler et al. 2013). Pressures to exploit Antarctic fisheries and oil, gas and mineral deposits are expected to increase as the global population grows (Q.58). Interest in discovering new biological products and pressures from tourism are both mounting and may diminish Antarctic wilderness values (Q.78). Possible land-based and expanded adventure tourism may strain current tourism regulatory regimes (Bastmeijer et al. 2008). Technological advances and climate change may enable large-scale, direct human modifications of the 
Antarctic environment and facilitate access to regions once thought to be protected by their sheer isolation and inhospitable nature (Q.75 and Q.77). As more people visit and the scope of activities diversifies, the risk of introduction of invasive species (Q.55), diseases and pathogens, whose impacts and abilities to adapt to the Antarctic environment are now only beginning to be understood (Frenot et al. 2005, Convey et al. 2014), will increase (Q.56 and Q.80). How humans themselves, and their behaviours, will adapt to and mitigate the risks of more frequent and longer stays in this extreme environment remains an open question (Q.80).

While many states have yet to accede to the Antarctic Treaty and its conservation measures and conventions, national interest in establishing or expanding operations in Antarctica signal changing priorities and motivations for a presence in the region (Q.76) (Brady 2012). The Antarctic governance regime is being tested by these pressures as it manages progressively more intractable environmental concerns within a changing Antarctic security and geopolitical framework (Q.76) (Hemmings 2009, Dodds 2010, Rothwell 2010, Joyner 2011, Chown et al. 2012b, Foster 2013, Hemmings et al. 2013).

Antarctic international governance, and much of the co-operation in scientific endeavours, is grounded in the Antarctic Treaty System. The number of nations that are signatories or have acceded to the regulatory framework of the Antarctic Treaty has increased in recent years (e.g. Monaco 2008, Belarus 2009, Portugal 2011, Malaysia 2011 and Pakistan 2012) and now number fifty. This includes a significant percentage of the world's population; however, it is less than $26 \%$ of the 193 member nations of the United Nations, and there are noticeable regions of the world that are not represented, including Africa and the Middle East. Since the inception of the Treaty, only 17 additional countries have risen to the level of a signatory which allows full participation in decision making. National interest in establishing or expanding operations has led to the establishment of new Antarctic stations (e.g. Belgium, India, China and Korea), the replacement of aging stations (e.g. UK and Germany) and the building of ice capable ships to increase access (e.g. China and Korea). States that have not acceded to the Antarctic Treaty may have interests in resource exploitation in the Antarctic, and non-state actors may become important. External pressures and changing global geopolitical configurations may adversely affect Antarctic governance and the conduct of science (Q.77).

Many of the challenges resulting from the presence of humans in Antarctica can only be addressed with a sound science evidence base. If Antarctica's ecosystems and intrinsic values are to be protected, lessons learned elsewhere and the principles of modern conservation science must be applied (Shaw et al. 2014). The efficacy of various conservation strategies will depend on being able to document attainment of their objectives through sciencebased approaches (Q.51, Q.66 and Q.68). The goal of sustainable management of marine resource extraction, such as fisheries, can best be supported through evidencebased management within the context of a changing climate (Q.58 and Q.61). Robust predictions of future human activities in Antarctica and understanding the value humans place on Antarctica (Grant et al. 2013) (Q.79) are essential. The recognition of the role that humans play in observed change relies on being able to discern anthropogenic change from natural variability to inform conservation and protection efforts, and policy making (Q.74).

\section{The way forward}

\section{Technological challenges and extraordinary logistical requirements}

Answering the 80 scientific questions identified through the horizon scan will require solutions to a wide array of technological challenges, and extraordinary logistical support and access to Antarctica and the Southern Ocean. Innovative experimental designs, new applications of existing technology, invention of next-generation technologies and the development of novel air-, spaceand animal-borne observing or logging technologies will be essential. Methodologies, instruments and sensors, from those that can probe at the cellular level to those that can see to the edge of the universe, will be needed. Some of these observing technologies will need to be autonomously deployed for extended periods. New, unbiased and 'clean' methodologies are required for the retrieval of samples of air, biota, sediment, rock, ice and water under challenging conditions in remote locations such as beneath ice shelves, the deep sea and under ice sheets.

Future research in Antarctica will require expanded, year-round access to the continent and the Southern Ocean. Innovation is also needed to allow those who may never go to the ice to access information, data and samples in real-time or through archives, databases and repositories. Improved coupled, integrated models are essential to portray what is a highly inter-connected and inter-dependent system of systems, if predictions with the precision and spatial resolution that are required for policy and decision making are to be possible. Astrophysics research, including cosmology, will require exquisitely sensitive sensors and facilities to house these capabilities on the high Antarctic plateau and deploy on ultra-long duration balloons. Networks of stations that continuously monitor the Earth's upper atmosphere in both polar regions will be essential to support near-Earth space research. Barriers to international collaboration need to be minimized, and new innovative, mutually beneficial and efficient models for partnerships that share 
ideas, data, logistics and facilities need to be explored. In turn, enhanced science support will require innovative and effective conservation and policy regimes to facilitate science while minimizing environmental compromises.

\section{Horizon scan lessons learned}

As the 1st Antarctic and Southern Ocean Science Horizon Scan, this view of the future will need to be revised and updated on a regular basis taking into account the latest scientific and global developments. Each scan begins with a set of assumptions and the current state-of-knowledge, and these underpinnings will undoubtedly change over time. Regular and sustained forward thinking exercises allow for course corrections and recognition of emerging trends that are critical to shorter timeframe strategic planning efforts.

Several lessons learned from this exercise will benefit future horizon scans. Preparation and consultation leading up to the final gathering of experts is essential to optimize the limited time available. A key element of the philosophy of a horizon scan is to set aside self-interest and short-term needs, and to focus on the future of the science a whole. Early selection and engagement of a sub-set of people to lead discussions and produce scan reports is essential. A cadre of experienced assistants conversant with the technologies and methodologies of the scan is critical for ensuring that Retreat time is well spent and the process is efficiently managed. Sorting (binning) of questions at the onset, scheduling and merging of sessions during the Retreat, clustering of final questions, and naming of clusters/themes are all important elements of the process that require extensive discussion. The final cluster/theme 'names' are important in outreach and dissemination of the outcomes beyond the experts.

An extensive and well organized plan for the dissemination of horizon scan outputs is essential to optimize impact and visibility. Antarctic and Southern Ocean science objectives and questions should be globally connected and not overly parochial, having relevance beyond the region while maintaining a place for individual researchers and curiosity-driven science. The breadth of modern Antarctic science is wide and there are many 'communities'. Any vision must capture this full view with special effort to ensure that smaller communities are adequately represented. In the end, Antarctic and Southern Ocean science competes with all other areas of science for resources and is best justified on the excellence, impact and uniqueness of the opportunity.

\section{The promise of Antarctic and Southern Ocean science}

Society faces many daunting, global-scale issues including a warming atmosphere and ocean, rising sea level and threats to living systems and the services they deliver. Antarctic and Southern Ocean science has been (Nature web focus 2014), and will continue to be, critical for discerning how human actions are altering our planet. Building on the foundations of past successes, the new knowledge to be gained from next-generation Antarctic and Southern Ocean science will be essential for informing society's decisions as we try to discern those actions that are most likely to affect our planet's present trajectory.

The first horizon scan has laid out a detailed and ambitious roadmap that will require a co-ordinated portfolio of international scientific efforts to realize the potential offered by science in the southern polar regions. Furthermore, Antarctic science underpins the management and governance of Antarctica through the Antarctic Treaty System. The maintenance of the region as an international place for peace and scientific research relies on authoritative and objective scientific advice. Co-ordination of Antarctic and Arctic research will also be increasingly important, as both poles exert influences and respond to changes in the earth and climate systems in ways not seen elsewhere on the planet. A co-ordinated portfolio of cross-disciplinary science, based on new models of international collaboration, will be essential. No one scientist, programme or even nation can reach these lofty aspirations alone, and success will be borneout by the practical solutions delivered as we navigate our way together into an uncharted future.

\section{Acknowledgements}

The authors of this paper and the organizers of the 1st SCAR Antarctic and Southern Ocean Science Horizon Scan recognize the financial support that made this event possible. Major financial support was provided by the Tinker Foundation. Substantial financial support was provided by Antarctica New Zealand, The New Zealand Antarctic Research Institute, the Scientific Committee on Antarctic Research (SCAR), the Council of Managers of National Antarctic Programs (COMNAP), the Alfred Wegner Institut, Helmholtz Zentrum für Polar und Meeresforschung (Germany), and the British Antarctic Survey (UK). Support was provided by the Antarctic Climate \& Ecosystems Cooperative Research Centre (Australia), the Canadian Polar Commission, the Climate and Cryosphere Program, the Instituto Antártico Chileno, Kelly Tarlton's Sea Life Aquarium, the Korean Polar Research Institute, Monash University (Australia), the National Institute of Polar Research (Japan), New Zealand Post, the Polar Research Institute of China, the Programma Nazionale di Ricerche in Antartide (Italy) and the University of Malaya. The support of the SCAR Secretariat and Antarctica New Zealand staff is gratefully recognized. The authors thank three anonymous reviewers for their constructive 
comments that improved the manuscript. Finally, thank you to those that submitted questions and nominated Retreat attendees. The contribution of each author is specified in Supplemental Table S1.

\section{Supplemental material}

Two supplemental tables will be found at http://dx.doi. org/10.1017/S0954102014000674.

\section{References}

Aartsen, M.G., Abbasi, R., Abdou, Y. et al.; IceCube Collaboration. 2013. Measurement of atmospheric neutrino oscillations with IceCube. Physical Review Letters, 111, 10.1103/PhysRevLett. 111.081801 .

Ade, P.A.R., Aikin, R.W., Barkats, D., et al.; BICEP2 Collaboration. 2014. Detection of B-mode polarization at degree angular scales by BICEP2. Physical Review Letters, 112, 10.1103/ PhysRevLett.112.241101.

Baker, D.N., Li, X., Pulkkinen, A., Ngwira, C.M., Mays, M.L., Galvin, A.B. \& Simunac, K.D.C. 2012. A major solar eruptive event in July 2012: defining extreme space weather scenarios. Space Weather - The International Journal of Research and Applications, 11, 585-591.

BARNoSky, A.D., Hadly, E.A., BASCOMPTE, J., et al. 2012. Approaching a state shift in Earth's biosphere. Nature, 486, 52-58.

Bastmeijer, K., Lamers, M. \& Harcha, J. 2008. Permanent land-based facilities for tourism in Antarctica: the need for regulation. Review of European Comparative \& International Environmental Law, 17, 84-99.

Bintanja, R., van Oldenborgh, G.J., Drijfhout, S.S., Wouters, B. \& KATSMAN, C.A. 2013. Important role for ocean warming and increased ice-shelf melt in Antarctic sea-ice expansion. Nature Geoscience, 6, 376-379.

Bockheim, J., Vieira, G., Ramos, M., López-Martínez, J., Serrano, E., Guglielmin, M., Wilhelm, K. \& Nieuwendam, A. 2013. Climate warming and permafrost dynamics in the Antarctic Peninsula region. Global and Planetary Change, 100, 215-223.

Böning, C.W., Dispert, A., Visbeck, M., Rintoul, S.R. \& SchwarzKopf, F.U. 2008. The response of the Antarctic Circumpolar Current to recent climate change. Nature Geoscience, 1, 864-869.

Bowman, V.C., Francis, J.E. \& Riding, J.B. 2013. Late Cretaceous winter sea ice in Antarctica? Geology, 41, 1227-1230.

BRADY, A.M. 2012. Polar stakes: China's polar activities as a benchmark for intentions. China Brief, 12, 11-15.

Brandt, A., Gooday, A.J., Brandao, S.N. et al. 2007. First insights into the biodiversity and biogeography of the Southern Ocean deep sea. Nature, 447, 307-311.

Bromwich, D.H., Nicolas, J.P., Monaghan, A.J., Lazzara, M.A., Keller, L.M., Weidner, G.A. \& Wilson, A.B. 2013. Central West Antarctica among the most rapidly warming regions on Earth. Nature Geoscience, 6, 139-145.

Burton, M.G. 2010. Astronomy in Antarctica. Astronomy and Astrophysics Review, 18, 417-469.

Byrne, M. \& Przeslawski, R. 2013. Multistressor impacts of warming and acidification of the ocean on marine invertebrates' life histories. Integrative and Comparative Biology, 53, 582-596.

Carson, C.J., McLaren, S., Roberts, J.L., Boger, S.D. \& Blankenship, D.D. 2014. Hot rocks in a cold place: high sub-glacial heat flow in East Antarctica. Journal of the Geological Society, 171, 9-12.

Cary, S.C., McDonald, I.R., Barrett, J.E. \& Cowan, D.A. 2010. On the rocks: the microbiology of Antarctic Dry Valley soils. Nature Reviews Microbiology, 8, 129-138.
Chown, S.L., Huiskes, A.H.L., Gremmen, N.J.M. et al. 2012a. Continent-wide risk assessment for the establishment of nonindigenous species in Antarctica. Proceedings of the National Academy of Sciences of the United States of America, 109, 4938-4943.

Chown, S.L., Lee, J.E., Hughes, K.A. et al. 2012b. Challenges to the future conservation of the Antarctic. Science, 337, 158-159.

Clarke, A. \& Johnston, N.M. 2003. Antarctic marine benthic diversity. Oceanography and Marine Biology: an Annual Review, 41, 47-114.

Constable, A.J., Melbourne-Thomas, J., Corney, S.P., et al. 2014. Climate change and Southern Ocean ecosystems I: how changes in physical habitats directly affect marine biota. Global Change Biology, $10.1111 / \mathrm{gcb} .12623$

Convey, P., Chown, S.L., Clarke, A., et al. 2014. The spatial structure of Antarctic biodiversity. Ecological Monographs, 84, 203-244.

Cook, C.N., Possingham, H.P. \& Fuller, R.A. 2013a. Contribution of systematic reviews to management decisions. Conservation Biology, 27, 902-915.

Cook, C.P., van de Flierdt, T., Williams, T., et al. 2013b. Dynamic behaviour of the East Antarctic Ice Sheet during Pliocene warmth. Nature Geoscience, 6, 765-769.

Corr, H.F.J. \& Vaughan, D.G. 2008. A recent volcanic eruption beneath the West Antarctic Ice Sheet. Nature Geoscience, 1, 122-125.

DAlziEl, I.W.D. 2013. Antarctica and supercontinental evolution: clues and puzzles. Earth and Environmental Science Transactions of the Royal Society of Edinburgh, 104, 3-16.

De Bernardis, P., Ade, P.A.R., Bock, J.J., et al. 2000. A flat Universe from high-resolution maps of the cosmic microwave background radiation. Nature, 404, 955-959.

DeConto, R.M. \& Pollard, D. 2003. Rapid Cenozoic glaciation of Antarctica induced by declining atmospheric $\mathrm{CO}_{2}$. Nature, 421, 245-249.

DeConto, R., Galeotti, S., Pagani, M., Tracy, D., Schaefer, K., Zhang, T.J., Pollard, D. \& Beerling, D.J. 2012. Past extreme warming events linked to massive carbon release from thawing permafrost. Nature, 484, 87-91.

DeSantis, L., Levy, R., Naish, T., Rack, F., DeConto, R. \& Escutia, C. 2009. Proposal for future Antarctic margin paleoclimate scientific drilling under the IODP. INVEST white paper. Granada: SCAR-ACE Symposium, $18 \mathrm{pp}$.

Ding, Q.H., Steig, E.J., Battisti, D.S. \& Kuttel, M. 2011. Winter warming in West Antarctica caused by central tropical Pacific warming. Nature Geoscience, 4, 398-403.

DodDs, K. 2010. Governing Antarctica: contemporary challenges and the enduring legacy of the 1959 Antarctic Treaty. Global Policy, 1, 108-115.

Elliot, D.H. \& Fleming, T.H. 2004. Occurrence and dispersal of magmas in the Jurassic Ferrar Large Igneous Province, Antarctica. Gondwana Research, 7, 223-237.

Foster, C.F. 2013. Antarctic resources and human security. In Hemmings, A.D., Rothwell, D.R. \& Scott, K.N., eds. Antarctic security in the twenty-first century: legal and policy perspectives. London and New York, NY: Routledge, 154-171.

Francis, J.E., Ashworth, A., Cantrill, D.J., Crame, J.A., Howe, J., Stephens, R., Tosolini, A.M. \& Thorn, V. 2008. 100 million years of Antarctic climate evolution: evidence from fossil plants. In CoOPER, A. K., Barrett, P.J., Stagg, H., Storey, B., Stump, E., Wise, W. \& the 10TH ISAES editorial teAm. eds. Antarctica: a keystone in a changing world. Washington, DC. The National Academic Press, 19-27.

Fraser, C.I., Nikula, R., Ruzzante, D.E. \& Waters, J.M. 2012. Poleward bound: biological impacts of Southern Hemisphere glaciation. Trends in Ecology \& Evolution, 27, 462-471.

Fraser, C.I., Terauds, A., Smellie, J., Convey, P. \& Chown, S.L. 2014. Geothermal activity helps life survive glacial cycles. Proceedings of the National Academy of Sciences of the United States of America, 111, 5634-5639. 
Frenot, Y., Chown, S.L., Whinam, J., Selkirk, P.M., Convey, P., Skotnicki, M. \& Bergstrom, D.M. 2005. Biological invasions in the Antarctic: extent, impacts and implications. Biological Reviews, 80, 45-72.

Geruo, A., Wahr, J. \& Zhong, S. 2013. Computations of the viscoelastic response of a 3-D compressible Earth to surface loading: an application to Glacial Isostatic Adjustment in Antarctica and Canada. Geophysical Journal International, 192, 557-572.

Gille, S.T. 2008. Decadal-scale temperature trends in the Southern Hemisphere ocean. Journal of Climate, 21, 4749-4765.

Gómez, N., Mitrovica, J.X., Tamisiea, M.E. \& Clark, P.U. 2010. A new projection of sea level change in response to collapse of marine sectors of the Antarctic ice sheet. Geophysical Journal International, 180, 623-634.

Grant, S.M., Hill, S.L., Trathan, P.N. \& Murphy, E.J. 2013. Ecosystem services of the Southern Ocean: trade-offs in decisionmaking. Antarctic Science, 25, 603-617.

Groh, A., Ewert, H., Scheinert, M., Fritsche, M., Rülke, A., Richter, A., Rosenau, R. \& Dietrich, R. 2012. An investigation of Glacial Isostatic Adjustment over the Amundsen Sea sector, West Antarctica. Global and Planetary Change, 98, 45-53.

Gutt, J., Zurell, D., Bracegridle, T.J., et al. 2012. Correlative and dynamic species distribution modelling for ecological predictions in the Antarctic: a cross-disciplinary concept. Polar Research, 31, 10.3402/polar.v31i0.11091.

Gutt, J., Griffiths, H.J. \& Jones, C.D. 2013. Circumpolar overview and spatial heterogeneity of Antarctic macrobenthic communities. Marine Biodiversity, 43, 481-487.

Hanson, D., Hoover, S., Crites, A., et al. (SPTpol Collaboration). 2013. Detection of B-mode polarization in the cosmic microwave background with data from the South Pole telescope. Physical Review Letters, 111, 10.1103/PhysRevLett.111.141301.

Harley, S.L., Fitzsimons, I.C. \& Zhao, Y. 2013. Antarctica and supercontinent evolution: historical perspectives, recent advances and unresolved issues. Geological Society, London, Special Publications, 383, 1.1144/SP383.9.

Harvey, R. 2003. The origin and significance of Antarctic meteorites. Chemie der Erde-Geochemistry, 63, 93-147.

Hemmings, A.D. 2009. From the new geopolitics of resources to nanotechnology: emerging challenges of globalism in Antarctica. Yearbook of Polar Law, 1, 55-72.

Hemmings, A.D., Rothwell, D.R. \& Scott, K.N. 2013. Antarctic security in a global context. In Hemmings, A.D., Rothwell, D.R. \& Sсотт, K.N., eds. Antarctic security in the twenty-first century: legal and policy perspectives. London and New York, NY: Routledge, 328-336.

Holland, P.R. 2014. The seasonality of Antarctic sea ice trends. Geophysical Research Letters, 41, 4230-4237.

Hoover, S., Nam, J., Gorham, P.W., et al.; ANITA Collaboration 2010. Observation of ultrahigh-energy cosmic rays with the ANITA balloon-borne radio interferometer. Physical Review Letters, 105, 10.1103/PhysRevLett.105.151101.

Jaccard, S.L., Hayes, C.T., Martínez-Garcíal, A., Hodell, D.A., Anderson, R.F., Sigman, D.M. \& Haug, G.H. 2013. Two modes of change in Southern Ocean productivity over the past million years. Science, 339, 1419-1423.

JAMIESON, S.S.R., Sugden, D.E. \& Hulton, N.R. 2010. The evolution of the subglacial landscape of Antarctica. Earth and Planetary Science Letters, 293, 1-27.

Joyner, C.C. 2011. Potential challenges to the Antarctic Treaty. In Berkman, P.A., Lang, M.A., Walton, D.W.H. \& Young, O.R., eds. Science diplomacy: Antarctica, science, and the governance of international spaces. Washington, DC: Smithsonian Institution Scholarly Press, 97-102.

Joughin, I. \& Alley, R.B. 2011. Stability of the West Antarctic Ice Sheet in a warming world. Nature Geoscience, 4, 506-513.
Joughin, I., Smith, B.E. \& Medley, B. 2014. Marine ice sheet collapse potentially under way for the Thwaites Glacier basin, West Antarctica. Science, 344, 735-738.

Kerry, K.R. \& Riddle, M.J. 2009. Health of Antarctic wildlife. A challenge for science and policy. Berlin: Springer, $470 \mathrm{pp}$.

Khatiwala, S., Tanhua, T., Fletcher, S.M., Gerber, M., Doney, S. C., Graven, H.D., Gruber, N., McKinley, G.A., Murata, A., Rios, A.F. \& SABINE, C.L. 2013. Global ocean storage of anthropogenic carbon. Biogeosciences, 10, 2169-2191.

Klein, A.G., Sweet, S.T., Kennicutt, M.C. II, Wade, T.L., Palmer, T.A. \& Montagna, P. 2014. Long-term monitoring of the human impacts to the terrestrial environment at McMurdo Station. In Tin, T., Liggett, D., Maher, P.T., Lamers, M. Antarctic futures. Human engagement with the Antarctic environment. Berlin: Springer, 213-227 pp.

Lanzerotti, L.J. \& Park, C.G., eds. 2013. Upper atmosphere research in Antarctica. Washington, DC: American Geophysical Union, 264 pp.

Levitus, S., Antonov, J.I., Boyer, T.P., Baranova, O.K., Garcia, H.E., Locarnini, R.A., Mishonov, A.V., Reagan, J.R., Seidov, D., YAROSH, E.S. \& ZweNG, M.M. 2012. World ocean heat content and thermosteric sea level change (0-2000 m), 1955-2010. Geophysical Research Letters, 39, 10.1029/2012GL051106.

Li, X., Holland, D.M., Gerber, E.P. \& Yoo, C. 2014. Impacts of the north and tropical Atlantic Ocean on the Antarctic Peninsula and sea ice. Nature, 505, 538-542.

Llubes, M., Lanseau, C. \& Rémy, F. 2006. Relations between basal condition, subglacial hydrological networks and geothermal flux in Antarctica. Earth and Planetary Science Letters, 241, 655-662.

Lough, A.C., Wiens, D.A., Barcheck, C.G., Anandakrishnan, S., Aster, R.C., Blankenship, D.D., Huerta, A.D., Nyblade, A., YounG, D.A. \& WiLson, T.J. 2013. Seismic detection of an active subglacial magmatic complex in Marie Byrd Land, Antarctica. Nature Geoscience, 6, 1031-1035.

Marshall, J. \& SpeER, K. 2012. Closure of the meridional overturning circulation through Southern Ocean upwelling. Nature Geoscience, 5, 171-180.

Massom, R.A. \& Stammerjohn, S.E. 2010. Antarctic sea ice change and variability - physical and ecological implications. Polar Science, 4, 149-186.

Meredith, M.P., Garabato, A.C.N. \& HogG, A.M. 2012. Sensitivity of the overturning circulation in the Southern Ocean to decadal changes in wind forcing. Journal of Climate, 25, 99-110.

Mouginot, J., Rignot, E. \& Scheuchl, B. 2014. Sustained increase in ice discharge from the Amundsen Sea embayment, West Antarctica, from 1973 to 2013. Geophysical Research Letters, 41, 1576-1584.

Naish, T., Powell, R., Levy, R., et al. 2009. Obliquity-paced Pliocene West Antarctic Ice Sheet oscillations. Nature, 458, 322-328.

NASA. 2014. NASA exoplanet archive. Pasadena, CA: NASA exoplanet science institute. Available at: http://exoplanetarchive. ipac.caltech.edu/cgi-bin/ExoTables/nph-exotbls?dataset=planets (accessed June 2014).

NATURE WEB FOCus 2014. Ozone hole. Nature, available at: http://www. nature.com/nature/focus/ozonehole/\#overview (accessed 26 June 2014).

Nield, G.A., Barletta, V.R., Bordoni, A., King, M.A., Whitehouse, P.L., Clarke, P.J., Domack, E., Scambos, T.A. \& Berthier, E. 2014. Rapid bedrock uplift in the Antarctic Peninsula explained by viscoelastic response to recent ice unloading. Earth and Planetary Science Letters, 397, 32-41.

Polvani, L.M., Waugh, D.W., Correa, G.J.P. \& Son, S.W. 2011. Stratospheric ozone depletion: the main driver of twentieth-century atmospheric circulation changes in the Southern Hemisphere. Journal of Climate, 24, 795-812.

Pritchard, H.D., Ligtenberg, S.R.M., Fricker, H.A., Vaughan, D. G., van den Broeke, M.R. \& Padman, L. 2012. Antarctic ice-sheet loss driven by basal melting of ice shelves. Nature, 484, 502-505. 
Rignot, E., Velicogna, I., van den Broeke, M.R., Monaghan, A. \& LenAerts, J. 2011. Acceleration of the contribution of the Greenland and Antarctic ice sheets to sea level rise. Geophysical Research Letters, 38, 10.1029/2011GL046583.

Rignot, E., Mouginot, J., Morlighem, M., Seroussi, H. \& Scheuchl, B. 2014. Widespread, rapid grounding line retreat of Pine Island, Thwaites, Smith, and Kohler glaciers, West Antarctica from 1992 to 2011. Geophysical Research Letters, 41, 3502-3509.

Rintoul, S.R. 2011. The Southern Ocean in the Earth system. In Berkman, P.A., LANG, M.A., Walton, D.W.H. \& Young, O.R., eds. Science diplomacy: Antarctica, science and the governance of international spaces. Washington DC: Smithsonian Institution Scholarly Press, 175-187.

Rocchi, S., Armienti, P., \& Di Vincenzo, G. 2005. No plume, no rift magmatism in the West Antarctic Rift. Geological Society of America Special Papers, 388, 435-447.

Rogers, A.D., Johnston, N.M., Murphy, E.J. \& Clarke, A. 2012a. Antarctic ecosystems: an extreme environment in a changing world. Oxford: Wiley-Blackwell, $538 \mathrm{pp}$.

Rogers, A.D., Tyler, P.A., Connelly, D.P., et al. 2012b. The discovery of new deep-sea hydrothermal vent communities in the Southern Ocean and implications for biogeography. PLoS Biology, 10, 10.1371/journal.pbio.1001234.

Rose, K.C., Ferraccioli, F., Jamieson, S.S.R., Bell, R.E., Corr, H., Creyts, T.T., Braaten, D., Jordan, T.A., Fretwell, P.T. \& Damaske, D. 2013. Early East Antarctic Ice Sheet growth recorded in the landscape of the Gamburtsev Subglacial Mountains. Earth and Planetary Science Letters, 375, 1-12.

Rothwell, D.R. 2010. Sovereignty and the Antarctic Treaty. Polar Record, 46, 17-20.

Sarmiento, J.L., Gruber, N., Brzezinski, M.A. \& Dunne, J.P. 2003. High-latitude controls of thermocline nutrients and low latitude biological productivity. Nature, 427, 56-60.

Shepherd, A., Ivins, E.R., Geruo, A. et al. 2012. A reconciled estimate of ice-sheet mass balance. Science, 338, 1183-1189.

Schoof, C. \& Hewitt, I. 2013. Ice-sheet dynamics. Annual Review of Fluid Mechanics, 45, 217-239.

Shapiro, N. \& Ritzwoller, M.H. 2004. Inferring surface heat flux distributions guided by a global seismic model: particular application to Antarctica. Earth and Planetary Science Letters, 223, 213-224.

Shaw, J.D., Terauds, A., Riddle, M.J., Possingham, H.P. \& Chown, S. L. 2014. Antarctica's protected areas are inadequate, unrepresentative and at risk. PLoS Biology, 12, 10.1371/journal.pbio.1001888.

Sigmundsson, F., Pinel, V., Lund, B., Albino, F., Pagli, C., Geirsson, H. \& Sturkell, E. 2010. Climate effects on volcanism: influence on magmatic systems of loading and unloading from ice mass variations, with examples from Iceland. Philosophical Transactions of the Royal Society - Mathematical, Physical and Engineering Sciences, A368, 2519-2534.

Smith, T.E., Wall, D.H., Hogg, I.D., Adams, B.J., Nielsen, U.N. \& VIRGINIA, R.A. 2012. Thawing permafrost alters nematode populations and soil habitat characteristics in an Antarctic polar desert ecosystem. Pedobiologia, 55, 75-81.

Smith, W.O., Dinniman, M.S., Hofmann, E.E. \& Klinck, J.M. 2014. The effects of changing winds and temperatures on the oceanography of the Ross Sea in the 21st century. Geophysical Research Letters, 41, $1624-1631$

Sokolov, S. \& Rintoul, S.R. 2009. Circumpolar structure and distribution of the Antarctic Circumpolar Current fronts: 1. Mean circumpolar paths. Journal of Geophysical Research - Oceans, 114, 10.1029/2008JC005108.
Stammerjohn, S., Massom, R., Rind, D. \& Martinson, D. 2012. Regions of rapid sea ice change: an inter-hemispheric seasonal comparison. Geophysical Research Letters, 39, 10.1029/2012GL050874.

Stewart, I.S., Sauber, J. \& Rose, J. 2000. Glacio-seismotectonics: ice sheets, crustal deformation and seismicity. Quaternary Science Reviews, 19, 1367-1389.

Storey, B.C., Vaughan, A.P. \& Riley, T.R. 2013. The links between large igneous provinces, continental break-up and environmental change: evidence reviewed from Antarctica. Earth and Environmental Science Transactions of the Royal Society of Edinburgh, 104, 17-30.

Sutherland, W.J. \& Woodroof, H.J. 2009. The need for environmental horizon scanning. Trends in Ecology \& Evolution, 24, 523-527.

Sutherland, W.J., Fleishman, E., Mascia, M.B., Pretty, J. \& Rudd, M.A. 2011. Methods for collaboratively identifying research priorities and emerging issues in science and policy. Methods in Ecology and Evolution, 2, 238-247.

Sutherland, W.J., Freckleton, R.P., Godfray, H.C.J., et al. 2013. Identification of 100 fundamental ecological questions. Journal of Ecology, 101, 58-67.

Thomas, D.N. \& Dieckmann, G.S., eds. 2010. Sea ice, Second Edition. Oxford: Blackwell Publishing, 621 pp.

Thomson, S.N., Reiners, P.W., Hemming, S.R. \& Gehrels, G.E. 2013. The contribution of glacial erosion to shaping the hidden landscape of East Antarctica. Nature Geoscience, 6, 203-207.

Timmreck, C. 2012. Modeling the climatic effects of large explosive volcanic eruptions. Wiley Interdisciplinary Reviews: Climate Change, 3, 545-564.

Tin, T., Fleming, Z.L., Hughes, K.A., Ainley, D.G., Convey, P., Moreno, C.A., Pfeiffer, S., Scott, J. \& Snape, I. 2009. Impacts of local human activities on the Antarctic environment. Antarctic Science, 21, 3-33.

Tuffen, H. 2013. Melting ice and volcanic hazards in the twenty-first century. In Mcguire, B. \& Mastin, M. eds. Climate forcing of geological hazards. Chichester: John Wiley \& Sons, 78-107.

Turner, J., BARRAND, N.E., Bracegirdle, T.J., et al. 2013. Antarctic climate change and the environment: an update. Polar Record, 50, 237-259.

Vogel, S.W. \& TulaczyK, S. 2006. Ice-dynamical constraints on the existence and impact of subglacial volcanism on West Antarctic Ice Sheet stability. Geophysical Research Letters, 33, 10.1029/ 2006GL027345.

Wadham, J.L., Arndt, S., Tulaczyk, S., Stibal, M., Tranter, M., Telling, J., Lis, G.P., Lawson, E., Ridgwell, A., Dubnick, A., Sharp, M.J., Anesio, A.M. \& Butler, C.E.H. 2012. Potential methane reservoirs beneath Antarctica. Nature, 488, 633-637.

Wadham, J.L., De'Ath, R., Monteiro, F.M., Tranter, M., Ridgwell, A., RAISWEll, R. \& TUlACZYK, S. 2013. The potential role of the Antarctic ice sheet in global biogeochemical cycles. Earth and Environmental Science Transactions of the Royal Society of Edinburgh, 104, 55-67.

Wilson, D.S., Jamieson, S.S.R., Barrett, P.J., Leitchenkov, G., Gohl, K. \& LARTER, R.D. 2012. Antarctic topography at the Eocene-Oligocene boundary. Palaeogeography, Palaeoclimatology, Palaeoecology, 335, 24-34.

Woehler, E.J., Ainley, D. \& JABOUR, J. 2013. Human impacts to Antarctic wildlife: predictions and speculations for 2060. In Tin, T., LiggetT, D., LAMERS, M. \& MAHER, P., eds. Antarctic futures: human engagement with the Antarctic environment. Dordrecht: Springer, 27-60.

Yang, H., Kulesa, C.A., Walker, C.K., Tothill, N.F.H., Yang, J., Ashley, M.C.B., Cui, X., Feng, L., Lawrence, J.S., Luong-Van, D. M., McCaughrean, M.J., Storey, J.W.V., Wang, L., Zhou, X. \& ZHu, Z. 2010. Exceptional terahertz transparency and stability above Dome A, Antarctica. Publications of the Astronomical Society of the Pacific, 122, 490-494. 